\title{
Integration of two methods: buffer zone method and land property led urban conservation case study Tokat conservation plan
}

\author{
B. Ergen ${ }^{1}$, Y. B. Ergen ${ }^{2}$, M. Ergen ${ }^{2}$, K. Tobias $^{3}$ \& Z. Ergen ${ }^{4}$ \\ ${ }^{1}$ Department of City and Regional Planning, Bozok University, Turkey \\ ${ }^{2}$ Amasya University, Turkey \\ ${ }^{3}$ Technische Universität Kaiserslautern, Germany \\ ${ }^{4}$ Bozok University, Turkey
}

\begin{abstract}
Urban historic areas are threatened by a multifaceted problem of physical, social, functional, and economic degradation. Moreover, changing hands of urban historic areas often results in the loss of interest to protect the historic sites. As a result, the accumulated memories between the owners and the spatial structure begin to disappear. In this sense, the ownership of historic buildings becomes important. To illustrate this, an Anatolian town with historic sites, Tokat, was selected. In this paper land property-led urban conservation (LPLUC) was improved with the buffer zones method (BZM). Information technology was used in order to create the buffer zones. BZM helps to calculate covered areas and their quality, and also to compute the quality of buildings with their covered areas, which are tabulated in each buffer zone. The buffer zones were created with GIS and the data of the urban historic sites were computed with GIS.

This paper emphasizes, in the context of urban conservation land, the property-led conservation approach, the importance of using GIS in urban conservation processes and the impact of BZM in relation to the historic sites and the conservation plan of Tokat.
\end{abstract}

Keywords: urban conservation, land property, buffer zone method, GIS, urban conservation plan, Tokat. 


\section{Urban conservation and LPLUC}

The concept conservation is generally applied to wider planning considerations. Modern planning focuses on the ability of conservation to promote 'adaptive reuse', seeking a middle ground between the development industry and the public reactions against large-scale redevelopment [1]. Moreover, 'urban conservation aims to retain the identity of urban areas and preserve values of the past, [...] whereas conservation considers the whole conservation areas and deals with the management of the changes' [2].

Urban historic areas are sensitive areas that reflect past construction methods and living style of previous inhabitants to present-day, as well as give information about earlier socio-economic and political conditions. These areas are sensitive because they have special visual characteristics, urban patterns and buildings that differ from the present city. Degradation can easily occur in these areas due to building density, urban growth, increasing population, and lack of infrastructure. In particular, these areas are irresponsive to present conditions. The main problems these areas face are the changing social structure and natural obsolescence.

'Conservation of historic areas is a dynamic process. Local governments have a major role in this process to understand the needs of the citizens for betterbuilt environments' [3]. Urban conservation plans aim to solve the abovementioned social, economic, and physical problems of urban historic areas. Due to the sensitive character of urban historic areas, urban conservation plans are related to the social, economic and physical problems of urban historic areas. Conservation plans handle these problems at different scales ranging from the plan scale to architectural details. Renewal, restoration, reconstruction, re-use, regeneration, and revitalization are the tools of urban conservation plans. 'These tools should strengthen the participation of the actors and the continuity of the process; otherwise a fragmented management plan can not be enough for the conservation of the area' [3]. Two important issues can provide a wide range of participation in urban conservation processes. The first one is preventing changing hands of historic buildings; whereas the latter related to land property and ownership of buildings in urban historic areas. Participation in the making of conservation plans could be increased with ownership because people would like to preserve things when there is a sense of belonging.

Okyay [4] compares the process of the loss of quality in urban historic patterns as "loss of quality maelstrom". According to Okyay [4], loss of quality maelstrom in historic areas occurs in a sequence of 1) becoming a slum, 2) loss of demand for conservation and maintaining, 3) becoming dilapidated, 4) decreasing sources for rehabilitation, 5) decrease in rent, and 6) loss of quality. The main problems in this process are changing hands of urban historic areas, changing economic structure of cities, pressure of urban density, insufficient infrastructure, and modern buildings. In the process of changing hands, the demand for the protection of historic sites decreases. The memories between owners and spatial structure start to disappear. 
LPLUC is a key approach and tool for urban conservation areas, which has an embedded emphasis on the private sector as the lead actor of policy implementation [5, 6]. Couch [7] emphasizes 'enterprise zones' established by local governments where private investment can be stimulated in order to regenerate derelict urban areas. According to Lloyd and Black [5], LPLUC encompasses partnership between the public and private sectors with the former involved in the coordination of local infrastructure. Besides, LPLUC attracts private sector interests in urban conservation zones to prevail urban policies [5]. This paper tackles the LPLUC approach in buffer zones.

\section{Geographic information systems}

Geographical Information Systems (GIS) facilitates associating digitized CAD data (coordinated data) with attribute data (non-coordinated data); and provides cross and multi queries in order to evaluate and give meaning to the whole data. GIS can transform coordinated data into attribute data and create different analyses with these data in conservation plans. GIS provides many advantages in terms of speed, time efficiency, and cost. Conservation-oriented development plans require more detailed and numerous surveying works be carried out than other types of plans. The use of GIS has an important role in digitizing the base and land-surveying maps used for conservation-oriented development plans, preparing database and query and analysis of buildings' [8]. 'Developments in the information technologies have been providing various tools in order to handle data, among which GIS take precedence in managing complex spatial data especially for the disciplines dealing with spatial problems' [9].

In this research, GIS is utilized to create the transition zone between the historic fabric and the newly developed urban pattern and to evaluate public ownership and private ownership in the Conservation Plan of Tokat.

\section{Case study}

Tokat is a historical city with several registered buildings, located in the middle Black Sea Region in Turkey. 'There are several monuments in Tokat from the Danismend Dynasty, such as Yağıbasan Medresesi and Çukur Medrese (Moslem madrasah); the Seljuq Dynasty, such as Gök Medrese (1265), Halef Sultan Medresesi (Moslem madrasah) (1292), Vezir Ahmet Paşa Mosque and Tomb (1288), Alaca Mosque (1301) and Sünbül Baba Dervish Lodge (1292); the Ottoman Empire, such as Taşhan Commercial Building and several houses' [10]. With these historic monuments and houses, and its conservation plan Tokat was selected as the case of this paper. The increasing population puts pressure on the historic areas and changing hands of buildings and land ownership causes a decline in the desire of maintaining historic buildings in Tokat.

The population of Tokat gradually increases and the figures show that the city is under pressure by population. The population of the city was 113,100 (2000), 127,988 (2007), 124,496 (2008), 129,879 (2009), and 136,595 (2010) according to the data of Turkish Statistical Institute [11]. Rapid population and urban 
growth threaten the historic pattern of Tokat. The official registration of the historic areas of Tokat took place in the early 1990s and to maintain of this cultural heritage the Conservation-Oriented Plan was prepared.

The Tokat Conservation-Oriented Plan is based on property-led urban conservation. Property-led urban conservation means defining the stakeholders with the ownership of officially registered buildings in the urban conservation area. In this way, it is aimed to increase participation as without participation historic buildings cannot be maintained. Besides, it is accepted that tasks and responsibilities of public and/or private owners can be defined with this plan. The registered urban conservation area was divided into five project packages in order to execute the management of the urban conservation plan. Figure 1 shows the conservation-oriented plan area, sub-regions and project packages.

As seen in Figure 1, the registered urban conservation area is divided into 1) the conservation-oriented plan area, 2) conservation-oriented guiding projects, 3) public ownership project area, 4) public buildings projects, and 5) public open

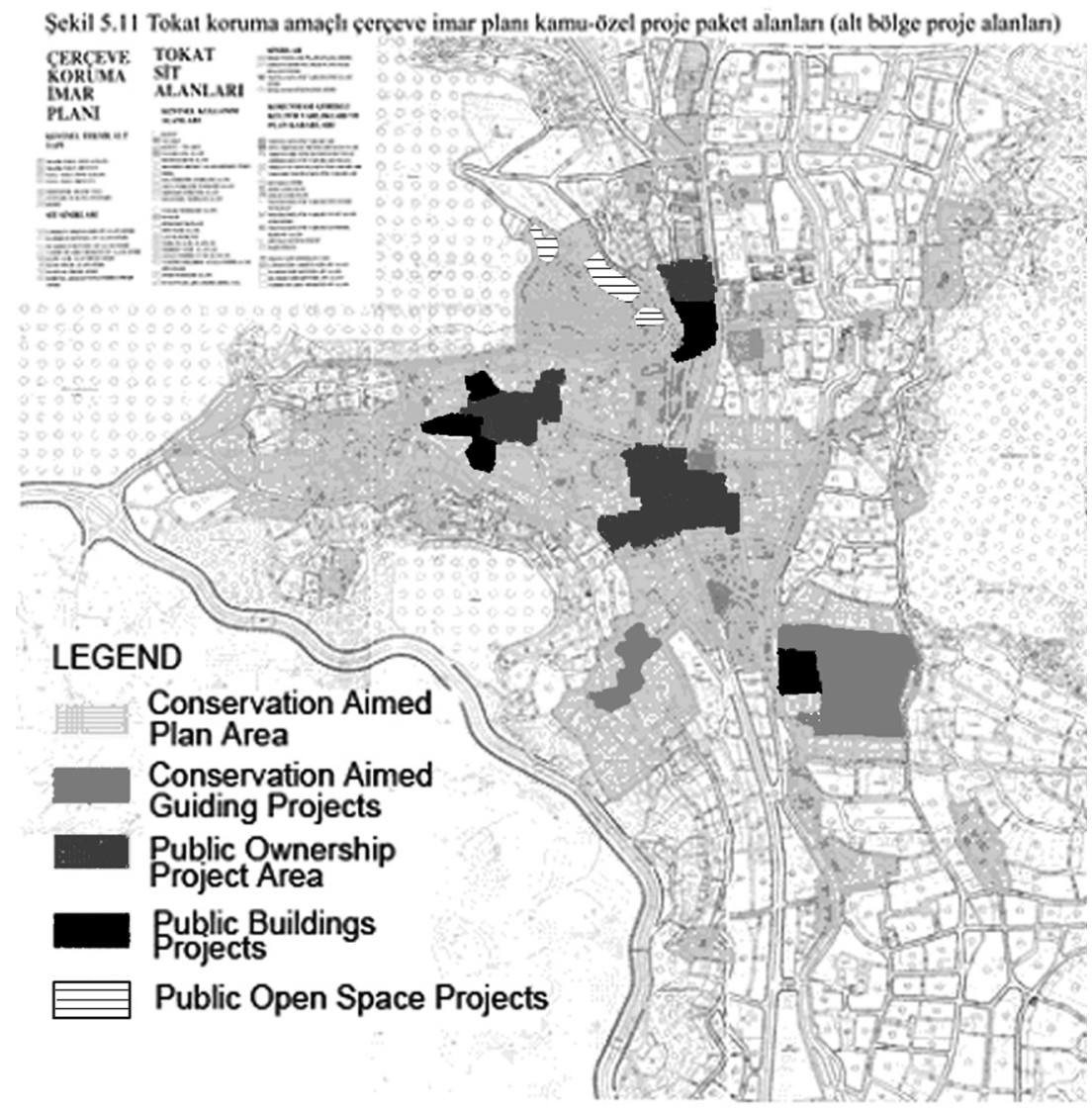

Figure 1: $\quad$ Urban conservation aimed plan of Tokat [12]. 
space projects. The plan area encompasses private ownership building area. Examples of civil architecture, especially from the Ottoman Empire epoch, can be seen in this area. Public open space projects area defines public open spaces, such as squares, streets, and parks. Public buildings projects encompass the ownership of the buildings that belong to public. These packages define important monumental buildings in the registered conservation area in Tokat, such as Taşhan Building, which is a commercial building from the Ottoman Empire epoch.

\section{Methodology}

Some historic buildings outside the urban conservation area still maintain their characteristics. However, these buildings cannot be registered within the urban conservation zone, resulting in a semi-degradation zone between the historic area and the modern city, which could be named transition zone. However, in the transition zone, there is no dominant characteristic; thus, these areas should be incorporated into the historical sites.

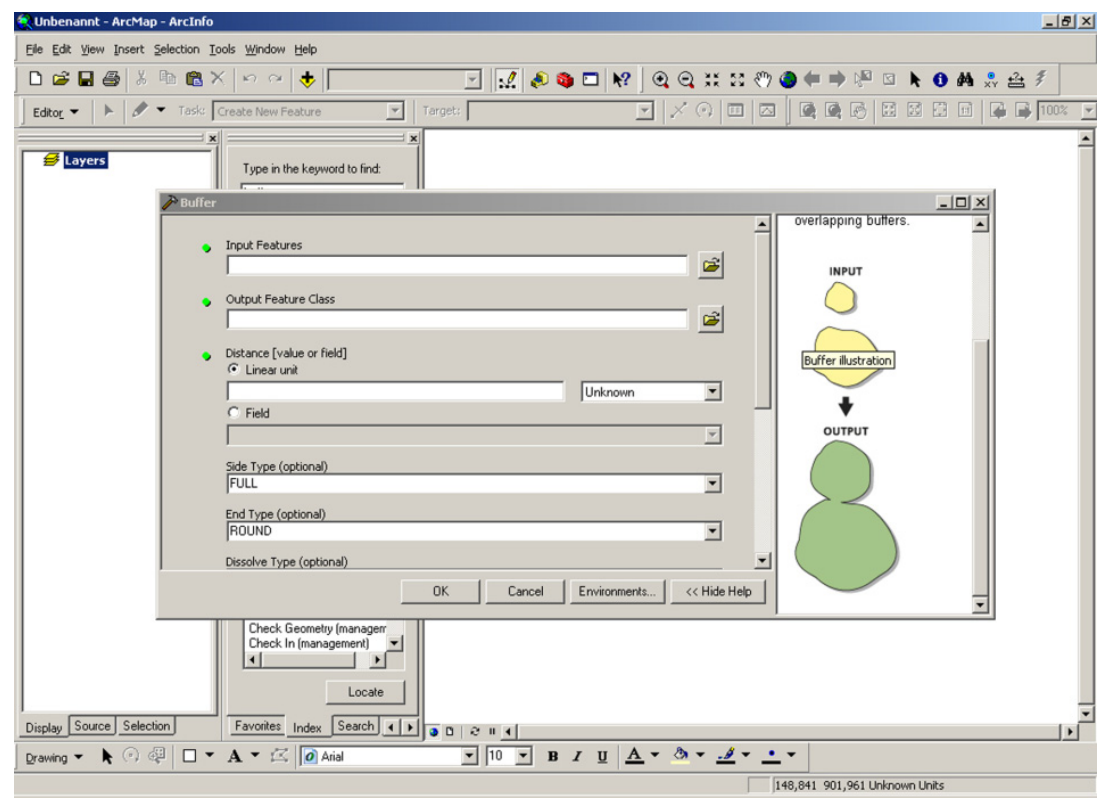

Figure 2: $\quad$ Utilizing ArcMap application GIS for methodology.

The methodology of this article is based on the integration of the historic zone and the transition zone with GIS. Li et al. [13] suggest a transition zone approach in their article. 'According to this model, a protected core area is surrounded by a buffer zone' and then a transition area. The core area and buffer zone should each have a definite boundary, and the transition zone as a whole is usually not strictly delineated' [13] Vass-Bowen stated that buffer zone planning can be 
adapted to heritage conservation and its strengths may prove useful in bridging the gap in current planning methodology as. He also argued that the fields of natural and cultural heritage conservation are closely related, with common problems associated with activities external to protected areas that threaten the very values for which these areas were granted their protected status. [14].

In this article, the conservation-oriented plan and its approach are integrated with GIS with the aim of preventing the process of loss of quality maelstrom. According to the model's approach, the transition zone and buffer zone are integrated, and a special conservation zone is suggested in order to protect the urban conservation area. In this research, ArcMap 9.2 was used to create buffer zones around the urban conservation area. Buffer Analysis is selected in index part of ArcMap in order to create a buffer zone around the urban conservation area. Figure 2 shows the display of the ArcMap application.

Buffer analysis facilitated the creation of a definite zone around an input value. The expanse of the buffer zone (value of field) was determined as $60 \mathrm{~m}$. according to the Construction Law no. 3194. The maximum side length of the

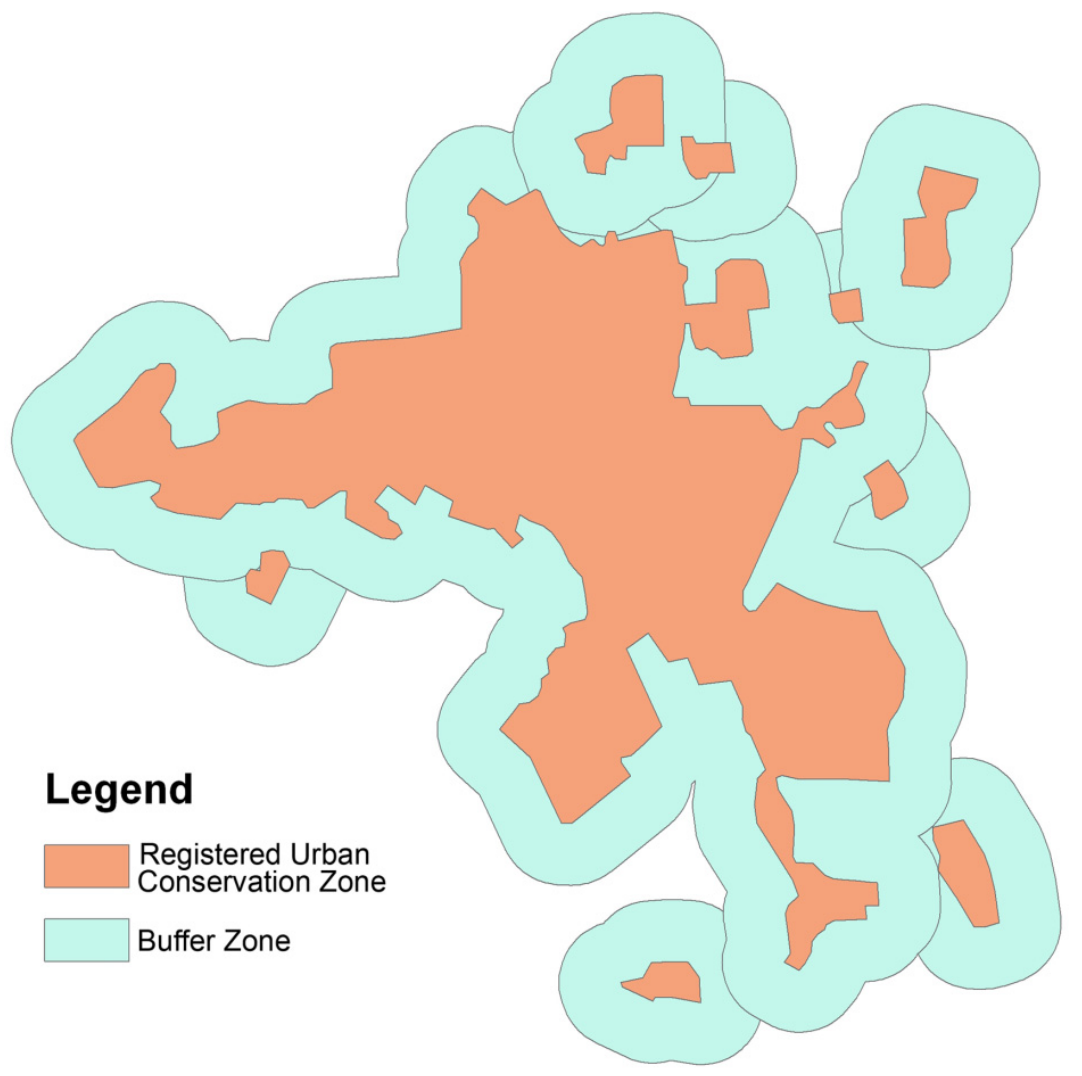

Figure 3: $\quad$ Result of buffer zone method in the Tokat conservation area. 
plot area was defined as $40 \mathrm{~m}$. according to the Planning Areas Act no. 3194. In this research, the average $30 \mathrm{~m}$. side length with two plots was accepted as the transition zone, resulting in a buffer zone of $60 \mathrm{~m}$. Following this, the output feature class was determined. As a result of this process, a shape file (shp) was created (seen in Figure 3). Figure 3 shows the result of the buffer analysis in the Tokat Urban Conservation Area. All of the registered conservation areas are integrated within the registered urban conservation zone. In addition, a special buffer zone is created between the modern city and the old historical city. This buffer zone also includes the transition zone in order to protect the core conservation area.

Although the buffer zone around the Tokat Conservation Area was determined as $60 \mathrm{~m}$., a simple matching coefficient (SMC) method is recommended to generalize the method of this article. 'SMC and simple matching distance are useful when both positive and negative values carry equal information'.

The formula is: $s_{i j}=\frac{p+s}{t}$; in this formula:

$p=$ number of variables that positive for both objects

$q=$ number of variables that positive for the $i$ th (core zone) objects and negative for the $j$ th (buffer zone) object

$r=$ number of variables that negative for the $i$ th (core zone) objects and positive for the $j$ th (buffer zone) object

$s=$ number of variables that negative for both objects

$t=p+q+r+s=$ total number of variables [15].

In this research, modern buildings, which are incongruous buildings in the urban conservation zone, were accepted as negative values. The historical buildings in the urban conservation zone were accepted as positive values. 'SMC is the similarity between the two cases which ranges from 0 to 1' [16]. When the result is close to 1 , the core zone and the buffer zone are more similar than the other cases. In this way, BZM can be generalized to the other urban conservation zones.

After the buffer analysis, the areas of historical buildings can be computed and tabulated. Tabulate Area (sa) was utilized in ArcMap 9.2 in order to compute covered areas of historic buildings in buffer zone.

\section{Discussion and conclusion}

GIS facilitates decision-making processes, digitizing the data, querying and analyzing historic fabrics. BZM is a method that integrates historic patterns with 
other regions of the city. In this way, it enables conservation-oriented plans to be accomplished and the realization of physical revitalization. However, the balance between conservation and development necessitates the consideration of a wider range of aspects. 'Conservation versus development' is a longstanding debate in both academic literature and professional practice. Determining the appropriate balance between conservation and development is still a key issue, as it has been throughout the history of modern planning' [17]. All urban areas need both 'continuity' and 'change'. Thus, a balance needs to be established in plans to choose the one in the interest of the community for whom the plan is being prepared [18].

Moreover, Kocabaş [19] argued that an evaluation of the impact of conservation planning should assess the outcomes in terms of three objectives:

- Physical: is the historic built environment preserved?

- Social: have the needs of existing residents been met during the process of upgrading the quality of the historic built environment?

- Economic: is conservation economically viable [17]?

'The body of research has shown that urban conservation increases the price or value of properties as justification to protect heritage building from demolition' [20]. Land property-led urban conservation increases the value of historic areas; therefore, the inhabitants continue living in the historic area. In this way, social sustainability could be provided. The increase in the land and building prices brings about the demand of maintaining historic buildings, so historic built environment could be preserved. Conservation of historic buildings could be economically viable as high purchase and sale prices of buildings and plots could provide the means to pay back the funds reason.

In this research, land property-led urban conservation has been integrated with GIS to merge the core zone and the transition zone with buffer zones. This method could help:

I. protect historic buildings located outside the urban conservation area,

II. integrate the historical pattern and the modern pattern of the city,

III. enlarge the urban conservation zone, and thus, to reduce the pressure created by urbanization, and

IV. revitalize the historic fabric of city.

In this generalization method, the expanse of the buffer zone around urban conservation zone is generalized with SMC. The number of the historic and modern buildings in the core zone and the buffer zone are proportioned. When the result is close to 1 , the buffer zone works more efficiently. In our example, the buffer zone according to the construction law no. 3194 works efficiently. However, as it could not be applied successfully to every place, the SMC method is required to compare the core zone and the buffer zone.

In buffer zones, the establishment of public and private enterprise areas is recommended in order to enable land property-led urban conservation. Public 
and private enterprises include technical support from public to private landowners, reducing property taxes in buffer zone, give technical support for restoration, consolidation, renovation, rehabilitation of debris and/or unconsolidated buildings, and creating public open spaces in buffer zones. In this way, LPLUC and BZM can be integrated into the buffer zone, thus, the historical environment can be maintained

The above-explained benefits of the integration of the two methods help prevent the loss of quality of urban historic areas, especially of physical built environments. Besides, the integration of these two methods facilitates the prevention of changing hands of historic buildings and lands in registered urban conservation zones.

\section{References}

[1] Larkham, P.T, The place of urban conservation in the UK reconstruction plans of 1942-1952. Planning Perspectives, 18 pp. 295-324, 2003.

[2] Lerotic, T, Evaluation of Historic Urban Areas by Using $3 D$ GIS Technologies-Case Study of Old City Istanbul Turkey, Unpublished Msc Thesis, University of Twente Faculty of ITC, 2011.

[3] Bagbanci, O.K, \& Bagbanci M.B, An Integrated Model of Urban Conservation and Revitalization from the Point of Immigration and Its Effects on Reyhan Urban Site in Turkey as a Case Study. World Academy of Science Engineering and Technology, 66 pp. 276-288, 2010.

[4] Okyay, İ., Kentsel Koruma ve Geliştirme Planlaması, Unpublished Master Course Notes, Mimar Sinan University.

[5] Lloyd, G., \& Black, S., Property-led urban regeneration and local economic development. Urban Regeneration: Property Investment and development, eds. J. Berry, S. McGreal, B. Deddis, E \& F N Spon an imprint of Chapman \& Hall: London, pp. 144-160, 1993.

[6] Healey, P. Models of the development process: A review. Journal of Property Research 8 (3) pp. 219-238, 1991.

[7] Couch, C., City of Change and Challenge: Urban Planning and Regeneration in Liverpool, Ashgate Publishing Limited: UK, pp. 111-134, 2003.

[8] Erdem, R., Durduran, S., Çay, T.,. Dülgerler, O.N, \& Yıldırım, H.H., An experimental study of GIS - aided conservation development plan; the case of Sille- Konya XIX CIPA Symposium - Antalya, Turkey - 30 September 4 October 2003, http://cipa.icomos.org/ANTALYA.html

[9] Naycı, N., Altınöz-Bilgin A.G., \& Güçhan-Şahin, N., An appraisal of the utilization of GIS in an urban conservation project in Antakya, XIX CIPA Symposium - Antalya, Turkey - 30 September - 4 October 2003, http://cipa.icomos.org/ANTALYA.html

[10] Aktüre, S., 19. Yüzyıl Sonunda Anadolu Kenti Mekansal Yapı Çözümlemesi, ODTÜ Mimarlık Fakültesi Basım İşliği: Ankara, pp. 143-145, 1987.

[11] Turkish Statistical Institute, http://tuikapp.tuik.gov.tr/adnksdagitapp/ $\underline{\text { adnks.zul }}$ 
[12] Ergen, B., Kentsel Koruma ve Kentsel Tasarım İlişkisi Üzerine Bir Araştırma: Tokat Örneği, Unpublished Msc Thesis, Yıldız Technical University, 2006.

[13] Li, W., Wang, Z., \& Tang, H., Designing the buffer zone of a nature reserve: a case study in Yancheng Biosphere Reserve China. Biological Conservation 90 pp. 159-165, 1999.

[14] Kozlowski, J., \& Peterson, A., Integrated Buffer Planning: towards Sustainable Development, Ashgate Publishing Limited: UK, pp. 257-294, 2005.

[15] Teknomo, K., http://people.revoledu.com/kardi/tutorial/Similarity/ SimpleMatching.html (Date Accessed, 28.02.2012).

[16] Aldenderfer, M.S. \& Blashfield, R.K. Series: Quantitative Applications in the Social Sciences, SAGE Publications: UK, pp. 89, 1984.

[17] Kocabaş, A., Urban conservation in Istanbul: evaluation and reconceptualisation Habitat International 30 pp. 107-126, 2006.

[18] Lichfield, N., Economics in urban conservation, Cambridge: Cambridge University Press, p. 56, 1988.

[19] Kocabaș, A., Urban conservation planning and development outcomes in central Istanbul and central London: 1969-1989, Unpublished Ph.D. thesis, London South Bank University, UK 2000.

[20] Lee, L.M., Lim, Y.M., \& Aini, Y.N., Strategies for urban conservation: A case example of George Town Penang. Habitat International 32 pp. 293304, 2008. 